\title{
Philosophiques
}

\section{Livres reçus}

\section{Volume 17, numéro 1, printemps 1990}

URI : https://id.erudit.org/iderudit/027118ar

DOI : https://doi.org/10.7202/027118ar

Aller au sommaire du numéro

\section{Éditeur(s)}

Société de philosophie du Québec

ISSN

0316-2923 (imprimé)

1492-1391 (numérique)

Découvrir la revue

Citer ce document

(1990). Livres reçus. Philosophiques, 17(1), 167-167.

https://doi.org/10.7202/027118ar

Ce document est protégé par la loi sur le droit d'auteur. L'utilisation des services d'Érudit (y compris la reproduction) est assujettie à sa politique d'utilisation que vous pouvez consulter en ligne.

https://apropos.erudit.org/fr/usagers/politique-dutilisation/ 


\section{LIVRES REÇUS}

BERNHARDT, Jean, Hobbes, Que sais-je? Paris, P.U.F. 1989.

BOUDRIAS, Gilles, L'art de convaincre, Montréal, McGraw-Hill, 1989.

BOUTOT, J., Heidegger, Que sais-je ? Paris, P.U.F. 1989.

HUSSERL, Edmund, La philosophie comme science rigoureuse, Paris, P.U.F. 1989.

LÉVESQUE, Claude, Dissonance ; Nietzsche à la limite du langage, Montréal, Hurtubise, HMH, 1988.

MARTEL, Donald, Conscience et engagement, Montréal, McGraw-Hill, 1989.

ROSSET, Clément, L'esthétique de Schopenhauer, Paris, P.U.F. 1989.

SCHELlING, F.W.J., Philosophie de la révélation, Livre I, Paris, P.U.F. 1989.

SCHULTHESS, Daniel et MULLER, Philippe (éd.), La révolution française dans la pensée européenne, Neuchâtel, Les Presses Académiques Neuchâtel ; Lausanne, L'Âge d'Homme, 1989.

SIOUI, Georges, Pour une auto-histoire amérindienne, Québec, Les Presses de l'Université Laval, 1989.

TREMBLAY, Robert, Savoir-faire ; Précis de méthodologie pour le collège et l'Université, Montréal, McGraw-Hill, 1989. 